Sains Malaysiana 50(5)(2021): 1407-1414

http://doi.org/10.17576/jsm-2021-5005-19

\title{
Pterostilbene Supplementation Inhibits Early Inflammatory Response and Oxidative Stress in UVB-Induced BALB/C Mice
}

(Suplementasi Pterostilbene Merencat Tindak Balas Keradangan Awal dan Tekanan Oksidatif pada Tikus BALB/C yang Diaruh-UVB)

TaVa Shelan Nagapan, Wenna Nallance Lim, Ahmad Rohi GHaZali \& Dayang Fredalina BasRi*

\section{ABSTRACT}

Extended dermal exposure of ultraviolet B (UVB) can induce erythema, hyperpigmentation, epidermal hyperplasia and cancer. Natural active compound such as pterostilbene (PS) is a potential UV-protecting agent as it has broad biological activities. This study aimed to evaluate the photoprotective effect of pterostilbene on ultraviolet-B-induced BALB/c mice. Twenty-four female mice were randomised into four groups ( $n=6 / g r o u p)$ : vehicle control (VC); UVB irradiated only (UVB only); UVB irradiation treated with pterostilbene $10 \mathrm{mg} / \mathrm{kg}$ (PS10+UVB); (iv) UVB irradiation treated with pterostilbene $20 \mathrm{mg} / \mathrm{kg}$ (PS20+UVB). The PS treatments were given for 14 days, and UVB was given at dose $250 \mathrm{~mJ} /$ $\mathrm{cm}^{2}$ on days 9, 11, and 13 of the treatment periods. The results showed that PS lessened redness and scaling on the skin of UVB-irradiated mice. The skinfold thickness and epidermal thickness in the PS-treated group were significantly reduced $(p<0.05)$ in comparison with those in the UVB only group. The PS10 and PS20 groups (5.927 \pm 0.354 and $5.660 \pm 0.765 \mathrm{nmol} / \mathrm{g}$, respectively) demonstrated significantly decreased MDA levels $(P<0.05)$ relative to the UVB only group $(13.343 \pm 1.350 \mathrm{nmol} / \mathrm{g})$. The GSH level in both PS10 (0.555 $\pm 0.020 \mu \mathrm{mol} / \mathrm{mg})$ and PS20 $(0.568 \pm 0.055$ $\mu \mathrm{mol} / \mathrm{mg})$ groups increased significantly $(p<0.05)$ compared with that in the UVB only group $(0.376 \pm 0.025 \mu \mathrm{mol} / \mathrm{mg})$. $S O D$ activity in the PS20 group $(1.388 \pm 0.172 \mathrm{U} / \mathrm{min} / \mathrm{mg})$ increased significantly $(p<0.05)$ compared with that in the UVB only group $(0.561 \pm 0.034 \mathrm{U} / \mathrm{min} / \mathrm{mg})$. Histological observation showed that PS reduced leukocyte infiltration and epidermal hyperplasia. Hence, oral PS may exert a photoprotective effect by acting as an anti-inflammatory and antioxidant agent on UVB-irradiated mice skin.

Keywords: Inflammation; oxidative stress; photoprotection; pterostilbene; UVB

\section{ABSTRAK}

Pendedahan kulit terhadap cahaya ultraungu B (UVB) secara berpanjangan boleh menyebabkan eritema, hiperpigmentasi, hiperplasia epidermis dan kanser. Sebatian aktif semula jadi seperti pterostilbene (PS) berpotensi untuk digunakan sebagai agen perlindungan UV kerana ia mempunyai aktiviti biologi yang luas. Kajian ini bertujuan untuk menilai kesan pemfotolindungan pterostilbene terhadap tikus yang diaruh sinaran UVB. Dua puluh empat ekor tikus betina dibahagikan kepada empat kumpulan secara rawak: kumpulan kawalan negatif $(n=6)$, tanpa sinaran UVB dan rawatan; disinarkan UVB sahaja $(n=6)$; disinarkan UVB dan dirawat dengan pterostilbene $10 \mathrm{mg} / \mathrm{kg}(P S 10+U V B)$; disinarkan UVB dan dirawat dengan pterostilbene $20 \mathrm{mg} / \mathrm{kg}(P S 20+U V B)$. Rawatan PS diberikan selama 14 hari, manakala pendedahan kepada UVB diberikan dengan dos $250 \mathrm{~mJ} / \mathrm{cm}^{2}$ pada hari ke-9, -11, dan -13 dalam tempoh rawatan. PS telah mengurangkan kulit bersisik dan eritema pada tikus aruhan UVB. PS telah mengurangkan ketebalan lipatan kulit tikus secara signifikan $(p<0.05)$ berbanding dengan kumpulan tikus yang disinarkan UVB sahaja. Ketebalan epidermis juga menurun dengan signifikan $(p<0.05)$ berbanding dengan kumpulan UVB sahaja. Kumpulan PS10 (5.927 \pm 0.354 $\mathrm{nmol} / \mathrm{g})$ dan PS20 (5.660 $\pm 0.765 \mathrm{nmol} / \mathrm{g})$ telah menunjukkan penurunan paras MDA yang signifikan $(p<0.05)$ berbanding

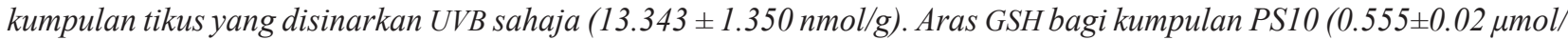
mol) dan PS20 (0.568 $\pm 0.055 \mu \mathrm{mol} / \mathrm{mol})$ telah meningkat secara signifikan $(p<0.05)$ berbanding dengan kumpulan tikus yang disinarkan UVB sahaja $(0.376 \pm 0.026 \mu \mathrm{mol} / \mathrm{mol})$. Kumpulan PS20 (1.388 $0.171 \mathrm{U} / \mathrm{min} / \mathrm{mg})$ telah menunjukkan peningkatan aktiviti SOD secara signifikan $(p<0.05)$ berbanding dengan kumpulan tikus yang disinarkan UVB sahaja

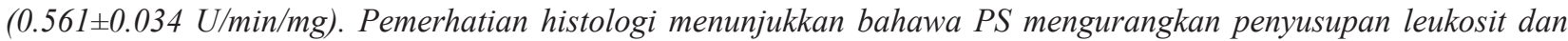
hiperplasia epidermis. Oleh itu, PS oral boleh memberikan kesan pemfotolindungan dengan bertindak sebagai agen anti-radang dan antioksidan pada kulit tikus yang disinarkan UVB.

Kata kunci: Keradangan; pemfotolindungan; pterostilbene; tekanan oksidatif; UVB 


\section{INTRODUCTION}

Skin is an external and the most susceptible organ that is continuously exposed to harmful environments such as solar ultraviolet (UV) radiation (Afaq 2011). UV radiation can be divided into three regions, namely, UVA (315$400 \mathrm{~nm})$, UVB (280-315 nm), and UVC (200-280 nm). Amongst these UV regions, UVB is 1,000 times stronger than UVA in causing sunburn (Wacker \& Holick 2013). UVB is also highly mutagenic as it can directly damage DNA through the formation of cyclobutane pyrimidine dimers and absorption of photoproducts (Ramasamy et al. 2017). Its radiation can penetrate the basal layer of the epidermis and affect the epidermal cells. UVB can also alter the proliferation, differentiation and metabolism of these cells and cause epidermal hyperplasia (D'Orazio et al. 2013).

Over-exposure of skin to UVB radiation will damage the cells through formation of reactive oxygen species (ROS). Overproduction of ROS may lead to lipid peroxidation of cell membranes and DNA and protein damage to tissues (Afaq \& Mukhtar 2006). ROS generation also decreases the levels of endogenous antioxidants, such as catalase, superoxide dismutase and reduced glutathione (GSH), causing an imbalance in the oxidant/antioxidant activities and reducing the ability of the skin to repair the damaged cells due to ROS (Afaq \& Mukhtar 2006; Gonzales-Castañeda et al. 2011).

In recent years, natural active compounds have also gained considerable attention in dermatological and cosmeceutical fields due to their broad biological activities. Pterostilbene is a natural active compound that can be isolated from blueberries, leaves of Vitis vinifera and heartwood of Pterocarpus marsupium and Pterocarpus santalinus (Chakraborty et al. 2010; Ma et al. 2019). Pterostilbene is a dimethylated analog of resveratrol; it has two methoxy groups and one hydroxyl group that allow it to have greater lipophilicity and higher potential for cellular uptake in comparison with resveratrol (Kapetanovic et al. 2011) Pterostilbene exerts strong antioxidant, anti-inflammatory, anticancer, and chemo-preventive properties. Pterostilbene has also been reported to inhibit metastatic activity in B16 melanoma cells (Ferrer et al. 2005). However, no study has examined the photoprotective effect of oral supplementation of pterostilbene on an in vivo model. Therefore, this study aimed to determine the photoprotective effects of oral pterostilbene in an UVB-induced BALB/c mice model.

\section{MATERIALS AND METHODS}

\section{EXPERIMENTAL DESIGN}

Twenty-four female BALB/c mice were purchased from the Faculty of Veterinary Medicine, Universiti Putra Malaysia. The animals were allowed to acclimatise for 1 week and maintained in standard conditions (12 h light/ dark cycle and 20.3-23.1 ${ }^{\circ} \mathrm{C}$ ) during the experimental cycle and fed with standard laboratory food and water ad libitum. The animals were kept at the animal house of the Department of Biomedical Science, Centre of Health and Applied Sciences, Universiti Kebangsaan Malaysia. All experimental procedures were reviewed and approved by the Universiti Kebangsaan Malaysia Animal Ethics Committee (UKMAEC; UKMAEC NO: FSK/2017/ AHMAD ROHI/22-NOV./887-NOV.-2017-JULY-2018) and the guidelines were strictly followed.

The animals were randomly divided into four groups: vehicle control group $(\mathrm{n}=6)$, which was not exposed to UVB irradiation and not treated with pterostilbene; the exposure group $(n=6)$, which was exposed to UVB irradiation only; and two treatment groups $(n=6)$, which were exposed to UVB irradiation and treated with 10 and $20 \mathrm{mg} / \mathrm{kg}$ pterostilbene, respectively. Pterostilbene treatment was supplemented via oral force-feeding for 14 successive days (Park et al. 2012).

\section{UVB IRRADIATION OF MICE}

Mice were irradiated by using a UVB lamp at a wavelength of $312 \mathrm{~nm}$ and 15 watts (UVP, USA). In brief, mice from both groups (UVB only and pterostilbene treatment groups) were exposed to UVB irradiation for $3 \mathrm{~min}$ at a dose of $250 \mathrm{~mJ} / \mathrm{cm}^{2}$ on days 9,11 , and 13 of treatment after shaving the dorsal part of the skin by using an electric shaver (Phillips, Malaysia) (Park et al. 2012). UVB emission was monitored regularly before each UVB irradiation with an UVX UV radiometer equipped with a UVX-31 sensor (UVP, USA).

\section{OBSERVATION OF SKIN MORPHOLOGY}

Visible diversification of the dorsal skin in mice was examined and photographed at the end of the experiment. The dorsal part of the skin was observed for any morphological changes in skin photodamage.

\section{MEASUREMENT OF SKIN OEDEMA}

Skinfold thickness was measured to assess skin oedema (Kim 2016). The mid-dorsal skinfold thickness was measured in groups of six mice by lifting them up at the neck and pinching the skin. Skinfold thickness was measured by using a Harpenden skinfold caliper (Baty, United Kingdom).

\section{EVALUATION OF OXIDATIVE STRESS AND ANTIOXIDANT} STATUS

Oxidative stress marker malondialdehyde (MDA) was quantified based on the reaction of MDA with thiobarbituric acid at $100{ }^{\circ} \mathrm{C}$ to form thiobarbituric acid reactive substances, which were measured at $532 \mathrm{~nm}$ (Stocks \& Dormandy 1971). Levels of antioxidants such as GSH were measured according to the Ellman method (Ellman 1959), and the level of superoxide dismutase (SOD) was measured based on its capacity to inhibit the reduction of ferricytochrome; the reaction was measured at $560 \mathrm{~nm}$ (Beyer \& Fridovich 1987). 


\section{HISTOLOGICAL OBERVATION AND DETERMINATION OF EPIDERMAL THICKNESS}

The fixed skin specimens were dehydrated with increasing concentrations of ethanol, embedded in paraffin to form paraffin blocks sectioned at $5 \mu \mathrm{m}$ thickness and stained with haematoxylin and eosin (H\&E) for histological evaluation. The epidermal thickness of stained sections was measured by ImageJ1.49 v software (NIH, Wayn Rasband, USA).

\section{STATISTICAL ANALYSIS}

Statistical analysis was conducted using Statistical Package for the Social Sciences (SPSS) version 23.0. The data were analysed by one-way ANOVA, followed by posthoc Tukey's test to estimate the significance differences between groups. Differences were statistically significant at $\mathrm{p}<0.05$. Data were then expressed as the mean \pm standard error of mean (SEM).

\section{RESULTS}

\section{PTEROSTILBENE ATTENUATES UVB-INDUCED EARLY} INFLAMMATORY RESPONSE

The effects of pterostilbene supplementation on UVB- irradiated mice were assessed by observing changes in skin morphology (Figure 1(A)-1(D)). We observed the presence of visible scaly skin in the UVB only group in comparison with the vehicle control group. The UVB only group also responded to erythema, hardening, and thickening of the skin in comparison with the vehicle control group (Figure 1(A) and 1(B)). Interestingly, both pterostilbene groups showed less erythema and no obvious skin scaling in comparison with the UVB only group (Figure 1(B)-1(D)). We also measured the skinfold thickness as an indicator of cutaneous edema. Figure 1(E) shows that the skinfold thickness of the UVB only group $(1.725 \pm 0.079 \mathrm{~mm})$ increased significantly compared with that in the vehicle control group $(1.000 \pm 0.035 \mathrm{~mm})$. However, both doses of pterostilbene (10 and $20 \mathrm{mg} / \mathrm{kg}$ ) significantly inhibited UVB-induced cutaneous edema, showing skinfold thickness $(1.200 \pm 0.061$ and $1.25 \pm 0.045$ $\mathrm{mm}$, respectively) as compared with the UVB only group $(1.725 \pm 0.079 \mathrm{~mm})$. In terms of the early inflammatory response, leukocyte infiltration was observed by H\&E staining (Figure 1(F)-1(I)). Histological observations proved that the UVB only group showed a marked increase of leukocyte infiltration in the dermal layer of the skin in comparison with the vehicle control. Oral supplementation of pterostilbene decreased leukocyte infiltration in the dermis compared with the UVB only group.
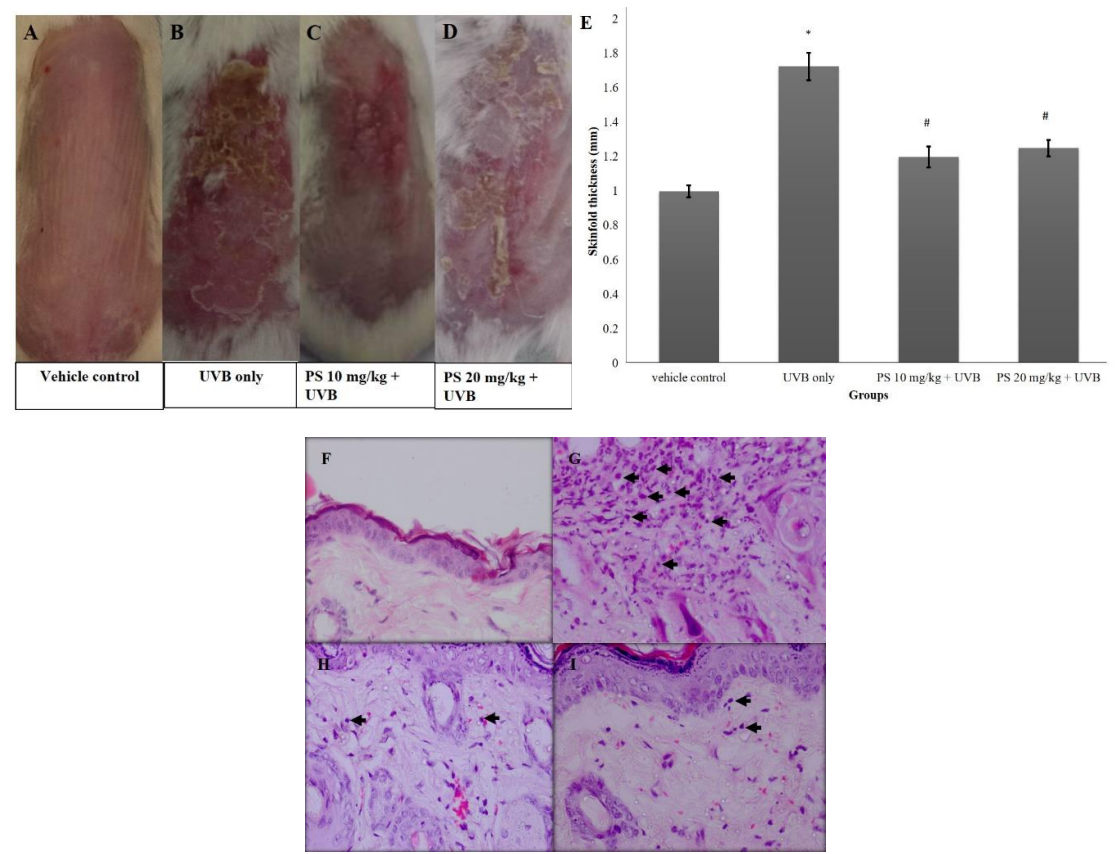

FIGURE 1. Effects of pterostilbene on early inflammatory response in UVB-irradiated mice. (A-D) Skin morphology was observed on day 15. (E). Evaluation of cutaneous oedema by measuring the skinfold thickness. Bar chart shows results of skinfold thickness in different groups represented by the mean \pm standard error mean (S.E.M) $(n=6)$ * Statistically significant difference in comparison with the vehicle control group $(\mathrm{P}<0.05)$. \# Statistically significant difference in comparison with the UVB exposure group $(\mathrm{P}<0.05)$. (F-I). Histological observation to show leukocyte infiltration (arrow) in the dermis layer by using haematoxylin and eosin staining. (F) Vehicle control group; (G) UVB only group; (H) PS $10 \mathrm{mg} / \mathrm{kg}$

+ UVB; (I) PS $20 \mathrm{mg} / \mathrm{kg}+$ UVB. Pictures are shown at a magnification of 40×. Scale bar: $100 \mu \mathrm{m}$ 


\section{PTEROSTILBENE AMELIORATES UVB-INDUCED EPIDERMAL HYPERPLASIA}

The epidermal thickness was measured and evaluated using Image J $1.49 \mathrm{v}$ software. The epidermal thickness of the UVB only group $(186.025 \pm 5.742 \mu \mathrm{m})$ increased significantly compared with that of the vehicle control group $(31.466 \pm 2.079 \mu \mathrm{m})$. Interestingly, the epidermal thickness of the $10(65.939 \pm 3.616 \mu \mathrm{m})$ and $20 \mathrm{mg} /$ $\mathrm{kg}(54.372 \pm 2.354 \mu \mathrm{m})$ pterostilbene groups decreased significantly compared with that of the UVB only group
$(186.025 \pm 5.742 \mu \mathrm{m})$. These findings could be supported with the histological analysis of the dorsal skin via $\mathrm{H} \& \mathrm{E}$ staining to evaluate epidermal hyperplasia. The vehicle control group showed the normal histology of the skin. However, the UVB only group showed obvious thickening of the epidermis of the skin in comparison with the vehicle control group. In addition, the UVB only group showed hyperkeratosis in the epidermis. However, the pterostilbene supplementation group showed a reduction in epidermal thickening as compared with the UVB only group (Figure 2).
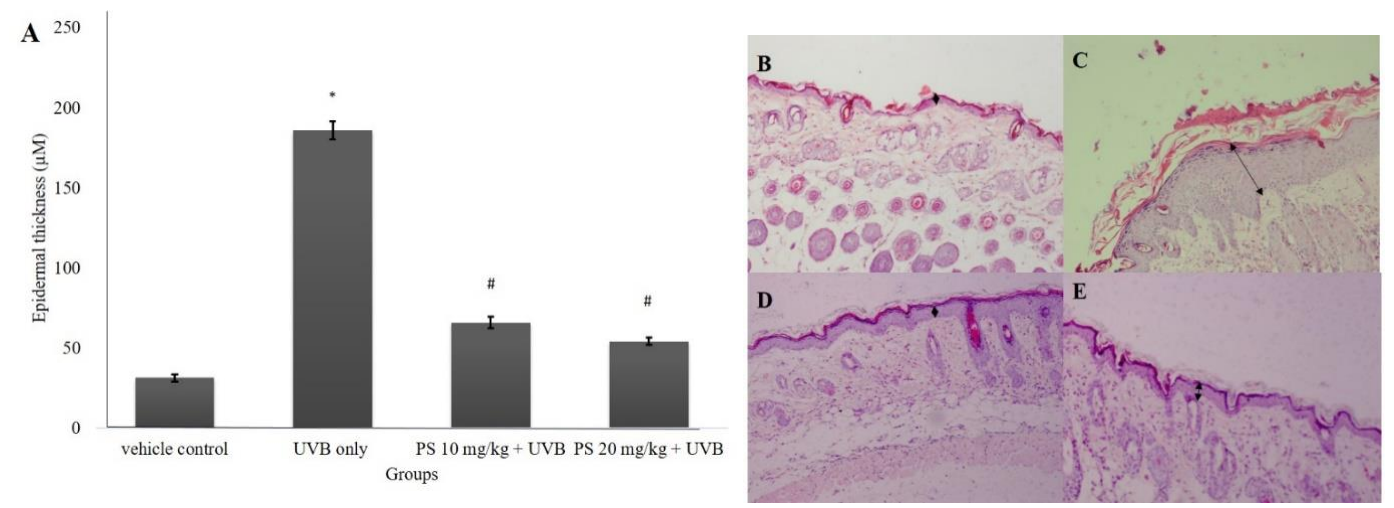

FIGURE 2. Effects of pterostilbene on epidermal hyperplasia in UVB-irradiated BALB/c mice. (A) Measurement of epidermal thickness by ImageJ1.49 v software. Bar chart shows the results of epidermal thickness in different groups represented by the mean \pm standard error mean (S.E.M) $(\mathrm{n}=6) . *$ Statistically significant difference in comparison with the vehicle control group (P $<0.05)$. \# Statistically significant difference in comparison with the UVB exposure group $(\mathrm{P}<$ 0.05). (B-E) Histological observation to show epidermal hyperplasia (double sided arrow) by using haematoxylin and eosin staining. (B) vehicle control group; (C) UVB only group; (D) PS $10 \mathrm{mg} / \mathrm{kg}$ + UVB; (E) PS $20 \mathrm{mg} / \mathrm{kg}+$ UVB. Haematoxylin-eosin staining; Pictures are shown at a magnification of $10 \times$. Scale bar: $100 \mu \mathrm{m}$

\section{PTEROSTILBENE DECREASES UVB-INDUCED OXIDATIVE STRESS}

UVB-induced oxidative stress was determined by evaluating the levels of MDA and antioxidants such as GSH and SOD. Figure 3(A) shows that the MDA level in the UVB only group $(13.343 \pm 1.350 \mathrm{nmol} / \mathrm{g})$ increased significantly $(\mathrm{p}<0.05)$ compared with that in the vehicle control group $(2.670 \pm 0.613 \mathrm{nmol} / \mathrm{g})$. However, both the 10 and $20 \mathrm{mg} / \mathrm{kg}$ pterostilbene groups $(5.927 \pm 0.354$ and $5.660 \pm 0.765 \mathrm{nmol} / \mathrm{g}$, respectively) demonstrated significantly decreased MDA levels compared with the UVB only group $(13.343 \pm 1.350 \mathrm{nmol} / \mathrm{g})$. Figure 3 (B) shows that the GSH level in the UVB only group $(0.376 \pm$ $0.025 \mu \mathrm{mol} / \mathrm{mg})$ decreased significantly $(\mathrm{p}<0.05)$ compared with that in the vehicle control group $(0.554 \pm 0.045 \mu \mathrm{mol} /$ $\mathrm{mg})$. By contrast, both the $10(0.555 \pm 0.020 \mu \mathrm{mol} / \mathrm{mg})$ and $20 \mathrm{mg} / \mathrm{kg}(0.568 \pm 0.055 \mu \mathrm{mol} / \mathrm{mg})$ pterostilbene groups showed significantly increased GSH levels $(\mathrm{p}<0.05)$ as 
compared with the UVB only group $(0.376 \pm 0.025 \mu \mathrm{mol} /$ $\mathrm{mg})$. Figure $3(\mathrm{C})$ shows that the UVB only group $(0.561$ $\pm 0.034 \mathrm{U} / \mathrm{min} / \mathrm{mg}$ ) exhibited significantly decreased SOD activity $(\mathrm{p}<0.05)$ compared with the vehicle control group $(1.142 \pm 0.156 \mathrm{U} / \mathrm{min} / \mathrm{mg})$. However, the $20 \mathrm{mg} / \mathrm{kg}$ pterostilbene group $(1.388 \pm 0.172 \mathrm{U} / \mathrm{min} / \mathrm{mg})$ exhibited a significant increase in SOD activity $(\mathrm{p}<0.05)$ compared with the UVB only group $(0.561 \pm 0.034 \mathrm{U} / \mathrm{min} / \mathrm{mg})$.
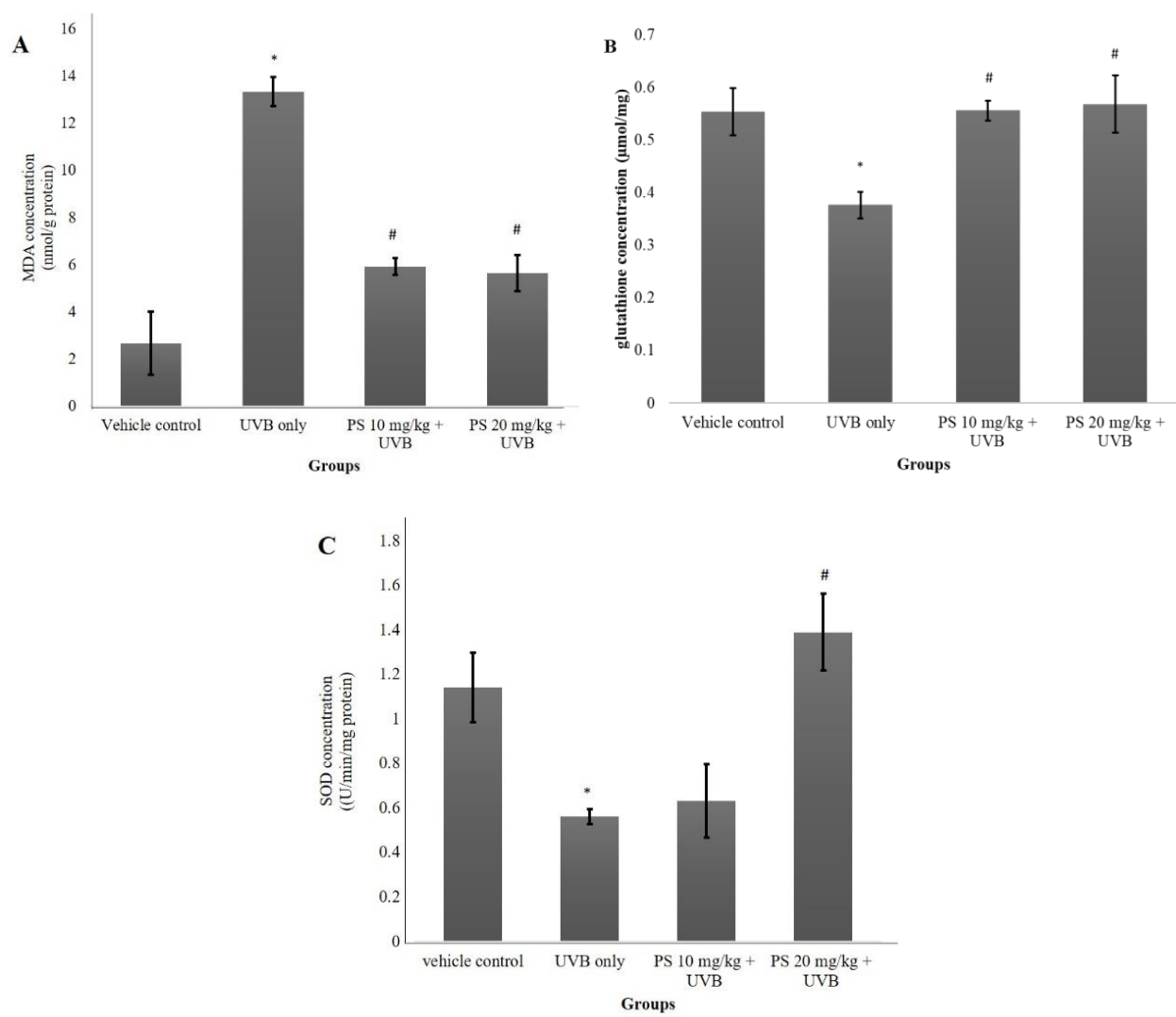

FIGURE 3. Effects of pterostilbene supplementation on oxidative stress in UV-irradiated BALB/c mice. (A) Bar chart shows results of the malondialdehyde (MDA) concentration in different groups represented by the mean \pm standard error mean (S.E.M) $(n=6)$. (B) Bar chart shows results of the glutathione concentration in different groups represented by the mean \pm standard error mean (S.E.M) $(n=6)$. (C) Bar chart shows the results of the glutathione concentration in different groups represented by the mean \pm standard error mean (S.E.M) $(n=6) . *$ Statistically significant difference in comparison with the vehicle control group $(\mathrm{P}<0.05)$. \# Statistically significant difference in comparison with the UVB exposure group $(\mathrm{P}<0.05)$

\section{DISCUSSION}

UV radiation present in sunlight is a class I carcinogen (Mogensen \& Jemec 2010). Extended exposure to UVB radiation may lead to significant biological complications to human skin, such as erythema, hyperpigmentation, peeling or dryness of skin and skin cancer (Nagapan et al. 2019). Therefore, there is current interest in identifying natural active compounds from plants that might prove to be of superior efficacy in protecting skin from photodamage (Nagapan et al. 2018a). Pterostilbene, a natural bioactive 
compound from blueberries, heartwood of $P$. marsupium and heartwood of $P$. santalinus, exhibits high oral bioavailability due to the presence of two methoxy groups, which leads to improved lipophilicity and cellular transit. In addition, pterostilbene increases the metabolic stability of molecules (Chen et al. 2017; Ghazali et al. 2012: Lin et al. 2009). Pterostilbene exhibits preventive and therapeutic properties against numerous human diseases due to its antioxidant capacity to reduce and scavenge ROS production (McCormack \& McFadden 2013). Hence, this study aimed to determine the photoprotective effects of pterostilbene supplementation on UVB-irradiated BALB/c mice.

A previous study reported that UVB exposure may lead to alterations in skin morphology such as erythema, peeling, and scaling of the skin (Petrova et al. 2011). These clinical manifestations are early signs of the inflammatory response. In this study, we also found similar clinical manifestations such as skin scaling and erythema in the UVB only group. Interestingly, the oral supplementation pterostilbene groups showed less erythema and no obvious skin scaling compared with the other groups. The formation of cutaneous oedema is one of the signs of acute UVB photodamage. Edema occurs when extracellular fluid accumulates due to excess leakage from the hyperpermeability of blood vessels (Sawane et al. 2011). Edema can be evaluated by measuring skinfold thickness (Kim 2016). In the present study, we discovered that pterostilbene reduced UVB-induced cutaneous oedema significantly compared with the UVB only group. On the basis of a previous study, pterostilbene was found to reduce ear skin oedema on hexavalent chromium-induced mice (Wang et al. 2018). Furthermore, cutaneous oedema was reported to be accompanied with significant leukocyte infiltration in the dermis layer of the skin. Our histological study showed that the UVB only group showed an increase in leukocyte infiltration in the dermis layer. However, the pterostilbene group exhibited markedly reduced infiltration of leukocytes in the dermal layer. Therefore, our findings suggested that pterostilbene supplementation could attenuate the early inflammatory response induced by UVB irradiation.

Epidermal hyperplasia is a histological hallmark for acute photodamage. Thickening of the epidermis occurs when UVB causes cell cycle arrest in keratinocytes. This mechanism is a protective effect to repair damaged cells (Marrot \& Meunier 2008; Ramasamy et al. 2017). However, prolonged exposure to UVB rapidly activates epidermal growth factor receptor (EGFR) and disrupts the cell cycle arrest that would progressively thicken the epidermal layer of the skin (El-abaseri et al. 2006). In the present paper, we reported that the UVB only group showed an increase in epidermal thickness as compared with the vehicle control group. Moreover, the UVB only group showed obvious epidermal hyperplasia in comparison with the vehicle control group. Interestingly, both pterostilbene groups showed a reduction in epidermal thickness and epidermal hyperplasia in comparison with the UVB only group. The postulated mechanism is that pterostilbene supplementation could control the activation of EGFR and induce cell cycle arrest in keratinocytes, thereby ameliorating UVB-induced epidermal hyperplasia. Previous studies reported that pterostilbene reduces benzo[a]pirene-induced epidermal hyperplasia (Singh et al. 2017). Topical application of pterostilbene also leads to a reduction in epidermal hyperplasia in UVB-irradiated hairless mice (Sirerol et al. 2015). Other stilbenes such as resveratrol also ameliorate epidermal hyperplasia in UVBinduced BALB/c mice (Nagapan et al. 2018b).

Acute exposure of UVB to skin can lead to oxidative stress by free radicals and ROS. This mechanism occurs when endogenous antioxidants such as SOD and GSH are depleted and lipid peroxidation activity increases. In addition, the main target of ROS on skin is lipids of the stratum corneum, which produces squalene peroxides; these peroxides cause the peroxidation of the cellular membrane of lipids (Auffray 2007). In this study, we demonstrated that UVB irradiation increased lipid peroxidation activity and decreased the contents of antioxidants such as SOD and GSH. However, these results showed that pterostilbene could protect cells by increasing the levels of antioxidants such as SOD and GSH while decreasing lipid peroxidation activity via the antioxidant defence mechanism. Pterostilbene is a potent activator of Nrf2 in which it controls the expression of genes whose protein products are involved in the detoxication and elimination of reactive oxidants and electrophilic agents via the Nrf2 signalling pathway. Previous studies showed that pterostilbene has been proven to have strong antioxidant capacity and free radical scavenging ability (Acharya \& Ghaskadbi 2013; Hasiah et al. 2011). The topical application of pterostilbene has also been reported to increase the SOD and GSH levels in UVB-irradiated hairless mice (Sirerol et al. 2015). These findings demonstrated that $20 \mathrm{mg} / \mathrm{kg}$ pterostilbene showed a maximum response (efficacy) as compared with $10 \mathrm{mg} / \mathrm{kg}$ pterostilbene. Based on the other findings in an in vivo model, $20 \mathrm{mg} / \mathrm{kg}$ pterostilbene showed better hepatoprotective effects in dimethylnitrosamine-induced liver fibrosis in rats than $10 \mathrm{mg} / \mathrm{kg}$ pterostilbene (Lee et al. 2012). 


\section{CONCLUSION}

In summary, pterostilbene supplementation could reduce the early inflammatory response and oxidative stress in UVB-irradiated BALB/c mice. Therefore, pterostilbene has the potential to be developed as a natural alternative for photoprotection.

\section{ACKNOWLEDGEMENTS}

This research work was funded by the Ministry of Higher Education, Malaysia (grant number FRGS/1/2019/SKK10/ UKM/01/1) and Universiti Kebangsaan Malaysia (grant number: DIP-2018-034).

\section{REFERENCES}

Afaq, F. \& Mukhtar, H. 2006. Botanical antioxidants in the prevention of photocarcinogenesis and photoaging. Experimental Dermatology 15(9): 678-684.

Auffray, B. 2007. Protection against singlet oxygen, the main actor of sebum squalene peroxidation during sun exposure, using Commiphora myrrha essential oil. International Journal of Cosmetic Science 29(1): 23-29.

Beyer, W.F. \& Fridovich, I. 1987. Assaying for superoxide dismutase activity: Some large consequences of minor changes in conditions. Analytical Biochemistry 161(2): 559-566.

Chakraborty, A., Gupta, N., Ghosh, K. \& Roy, P. 2010. In vitro evaluation of the cytotoxic, anti-proliferative and anti-oxidant properties of pterostilbene isolated from Pterocarpus marsupium. Toxicology in Vitro 24(4): $1215-$ 1228.

D’Orazio, J., Jarrett, S., Amaro-Ortiz, A. \& Scott, T. 2013. UV radiation and the skin. International Journal of Molecular Sciences 14(6): 12222-12248.

El-abaseri, T.B., Putta, S. \& Hansen, L.A. 2006. Ultraviolet irradiation induces keratinocyte proliferation and epidermal hyperplasia through the activation of the epidermal growth factor receptor. Carcinogenesis 27(2): 225-231.

Ellman, G.L. 1959. Tissue sulfhydryl groups. Archives of Biochemistry and Biophysics 82(1): 70-77.

Ferrer, P., Asensi, M., Segarra, R., Ortega, A., Benlloch, M., Obrador, E., Varea, M.T., Asensio, G., Jordá, L. \& Estrela, J.M. 2005. Association between pterostilbene and quercetin inhibits metastatic activity of B16 melanoma. Neoplasia 7(1): 37-47.

Ghazali, A.R., Ong, S.K., Hasiah, A.H. \& Kamarulzaman, F. 2012. Effects of pterostilbene on o-deethylation and glutathione conjugation of drug metabolizing enzyme activities. Pharmacologia 3(9): 456-461.

Kapetanovic, I.M., Muzzio, M., Huang, Z., Thompson, T.N. \& McCormick, D.L. 2011. Pharmacokinetics, oral bioavailability, and metabolic profile of resveratrol and its dimethylether analog, pterostilbene, in rats. Cancer Chemotherapy and Pharmacology 68(3): 593-601.
Kim, H.K. 2016. Garlic supplementation ameliorates UV-Induced photoaging in hairless mice by regulating antioxidative activity and MMPs expression. Molecules 21(1): 70-82.

Lee, M.F., Liu, M.L., Cheng, A.L., Tsai, M.L., Ho, C.T., Liou, W.S. \& Pan, M.H. 2012. Pterostilbene inhibits dimethylnitrosamine-induced liver fibrosis in rats. Food Chemistry 138(2-3): 802-807.

Ma, Z., Zhang, X., Xu, L., Liu, D., Di, S., Li, W., Zhang, J., Zhang, H., Li, X., Han, J. \& Yan, X. 2019. Pterostilbene: Mechanisms of its action as oncostatic agent in cell models and in vivo studies. Pharmacological Research 145: 104265.

Marrot, L. \& Meunier, J. 2008. Skin DNA photodamage and its biological consequences. Journal of the American Academy of Dermatology 58(5): 139-148.

McCormack, D. \& McFadden, D. 2013. A review of pterostilbene antioxidant activity and disease modification. Oxidative Medicine and Cellular Longevity 2013: 575482.

Mogensen, M. \& Jemec, G.B. 2010. The potential carcinogenic risk of tanning beds: Clinical guidelines and patient safety advice. Cancer Management and Research 2: $277-282$

Nagapan, T.S., Lim, W.N., Basri, D.F. \& Ghazali, A.R. 2019 Oral supplementation of L-glutathione prevents UVBinduced melanogenesis and oxidative stress in BALB/c mice. Experimental Animals 68(4): 541-548.

Nagapan, T.S., Ghazali, A.R., Basri, D.F. \& Lim, W.N. 2018a. Photoprotective effect of stilbenes and its derivatives against ultraviolet radiation-induced skin disorders Biomedical and Pharmacology Journal 11(3): 1199-1208.

Nagapan, T.S., Ghazali, A.R., Basri, D.F. \& Lim, W.N. 2018b. Oral administration of resveratrol ameliorates epidermal hyperplasia in ultraviolet B irradiated BALB/c mice. Journal of Applied Pharmaceutical Science 8(10): 47-52.

Park, J.M., Cho, J.K., Mok, J.Y., Jeon, I.H., Kim, H.S., Kang, H.J. \& Jang, S.I. 2012. Protective effect of astragalin and quercetin on ultraviolet (UV)-irradiated damage in HaCaT cells and BALB/C mice. Journal of the Korean Society for Applied Biological Chemistry 55(3): 443-446.

Petrova, A., Davids, L.M., Rautenbach, F. \& Marnewick, J.L. 2011. Photoprotection by honeybush extracts, hesperidin and mangiferin against UVB-induced skin damage in SKH-1 mice. Journal of Photochemistry and Photobiology B: Biology 103(2): 126-139.

Ramasamy, K., Shanmugam, M., Balupillai, A., Govindhasamy, K., Gunaseelan, S., Muthusamy, G., Robert, B.M. \& Nagarajan, R.P. 2017. Ultraviolet radiation-induced carcinogenesis: Mechanisms and experimental models. Journal of Radiation and Cancer Research 8(1): 4-19.

Sawane, M., Kidoya, H., Muramatsu, F., Takakura, N. \& Kajiya, K. 2011. Apelin attenuates UVB-induced edema and inflammation by promoting vessel function. The American Journal of Pathology 179(6): 2691-2697.

Singh, P., Arora, D. \& Shukla, Y. 2017. Enhanced chemoprevention by the combined treatment of pterostilbene and lupeol in $\mathrm{B}[\mathrm{a}] \mathrm{P}$-induced mouse skin tumorigenesis. Food and Chemical Toxicology 99: 182-189. 
Sirerol, J.A., Feddi, F., Mena, S., Rodriguez, M.L., Sirera, P., Aupí, M., Pérez, S., Asensi, M., Ortega, A. \& Estrela, J.M. 2015. Topical treatment with pterostilbene, a natural phytoalexin, effectively protects hairless mice against UVB radiation-induced skin damage and carcinogenesis. Free Radical Biology and Medicine 85: 1-11.

Stocks, J. \& Dormandy, T.L. 1971. The autoxidation of human red cell lipids induced by hydrogen peroxide. British Journal of Haematology 20(1): 95-111.

Wacker, M. \& Holick, M.F. 2013. Sunlight and vitamin D: A global perspective for health. Dermatoendocrinology 5(1): 51-108.

Tava Shelan Nagapan, Wenna Nallance Lim \& Ahmad Rohi Ghazali

Biomedical Science Programme

Centre for Toxicology and Health Risk Studies

Faculty of Health Sciences

Universiti Kebangsaan Malaysia

Jalan Raja Muda Abdul Aziz

50300 Kuala Lumpur, Federal Territory

Malaysia
Dayang Fredalina Basri*

Biomedical Science Programme

Centre for Diagnostic, Therapeutic and Investigations Faculty of Health Sciences

Universiti Kebangsaan Malaysia

Jalan Raja Muda Abdul Aziz

50300 Kuala Lumpur, Federal Territory

Malaysia

*Corresponding author; email: dayang@ukm.edu.my

Received: 6 January 2020

Accepted: 29 September 2020 